Manajemen Konflik... Oleh: Zaenal Arifin

\title{
MANAJEMEN KONFLIK PADA KEPEMIMPINAN KOLEKTIF BPK-P2L PONDOK PESANTREN LIRBOYO KEDIRI $^{1}$
}

\author{
Oleh \\ Zaenal Arifin \\ Institut Agama Islam Tribakti Kediri \\ email :zae.may13@gmail.com
}

\section{Abstracts}

This article is the result of a study that discusses conflict management implemented in the collective leadership of the Lirboyo Kediri Islamic Boarding School. Where the Lirboyo Kediri boarding school is one of the largest pesantren in the province of East Java and has also existed for more than a century and now its leadership is in the hands of the 4th generation who is the grandson of the founder of the pesantren. In carrying out its leadership, the Lirboyo Kediri boarding school uses a collective leadership style incorporated in a forum called BPK-P2L (Lirboyo Kediri Islamic Boarding School Board of Trustees).

The results of this study conclude first, that the formation of the Lirboyo Kediri BPK-P2L Islamic Boarding School has the motive to maintain the integrity of the zealous ties of the pesantren. Second, the map of potential conflicts in the Lirboyo Kediri boarding school consists of: 1). The Lirboyo Kediri boarding school has unit boarding schools that are independent and have their own caregivers and organizations but on the other hand must also comply with the BPK-P2L decision, 2). Term of pondok kulon and pondok wetan. Third, that in conflict control BPK-P2L Lirboyo Kediri applies the musayawarah approach, the

\footnotetext{
${ }^{1}$ Penelitian ini didanai oleh DIPA Direktorat Pendidikan Tinggi Islam Direktorat Jenderal Pendidikan Islam Kementrian Agama Tahun Anggaran 2017
} 
division of roles and authority, and applies the tradition of marriage between relatives.

\begin{abstract}
Abstrak
Artikel ini merupakan hasil penelitian yang membahas tentang manajemen konflik yang diimplementasikan pada kepemimpinan kolektif di Pondok Pesantren Lirboyo Kediri. Dimana pesantren Lirboyo Kediri merupakan salah satu pesantren tersbesar di provinsi Jawa Timur dan juga telah eksis selama 1 abad lebih dan saat ini tampuk kepemimpinannya berada di tangan generasi ke 4 yang merupakan cucu dari (muasis) pendiri pesantren tersebut. Dalam menjalankan kepemimpinannya, pesantren Lirboyo Kediri menggunakan gaya kepemimpinan kolektif yang tergabung dalam wadah yang bernama BPK-P2L (Badan Pembina Kesejahteraan Pondok Pesantren Lirboyo Kediri).

Hasil penelitian ini menyimpulkan pertama, bahwa pembentukan BPK-P2L Pesantren/Lirboyo Kediri memiliki motif untuk menjaga keutuhan ikatan kekerabatan dzuriah pesantren. Kedua, peta potensi konflik yang ada di pesantren Lirboyo Kediri terdiri dari: 1). Pesantren Lirboyo Kediri memiliki unit-unit pesantren yang berdiri sendiri dan memiliki pengasuh serta organisasi tersendiri tetapi di sisi lain juga harus patuh pada keputusan BPK-P2L, 2). Term pondok kulon dan pondok wetan. Ketiga, bahwa dalam pengendalian konflik BPK-P2L Lirboyo Kediri menerapkan pendekatan musayawarah, pembagian peran dan wewenang, serta menerapkan tradisi pernikahan antar kerabat.
\end{abstract}

Kata Kunci : Manajemen Konflik, Kepemimpinan Kolektif, BPKP2L Pesantren Lirboyo Kediri

\title{
Pendahuluan
}

Penelitian ini akan melihat dan memahami perilaku kepemimpinan kolektif sebagai manajemen konflik di pondok 
pesantren Lirboyo Kediri, dimana pesantren Lirboyo Kediri merupakan salah satu pondok pesantren tertua dan terbesar di provinsi Jawa Timur. ${ }^{2}$ Pesantren ini juga merupakan pesantren salaf tertua dengan jaringan alumni yang telah menyebar hampir di seluruh daerah di Indonesia dan menempati posisi penting dalam kiprahnya di masyarakat. Selain itu, Pesantren Lirboyo Kediri memiliki pesantren-pesantren unit hingga 10 unit lebih yang tersebar di sekeliling pesantren induk (utama), dan masingmasing unit memiliki karakter dan konsentrasi yang berbeda-beda dalam menyelenggarakan pendidikannya. Semua pesantren unit Lirboyo kediri didirikan oleh dzuriyah (keluarga) yang tergabung dalam BPK-P2L (Badan Pembina Kesejahteraan Pondok Pesantren Lirboyo). ${ }^{3}$

Pondok Pesantren Lirboyo Kediri didirikan pada tahun 1910 oleh KH Abdul Karim ${ }^{4}$, atas dorongan dari mertuanya yang

2 Pondok pesantren Lirboyo Kediri didirikan oleh KH. Abdul Karim (mbah Manab) pada tahun 1910. Saat ini Pesantren Lirboyo Kediri telah memiliki 10 unit adalah 1). PPHM (disebut Pondok Pesantren Induk dengan jumlah santri 730), 2). P3HM (disebut dengan Unit HM Ceria dengan jumlah santri 990), 3). PPHM al-Mahrusiyah Putra/PPHM al-Mahrusiyah Putri (disebut Unit HMP dengan jumlah santri 1.709, 4). PPHMA (disebut Unit HM Antara dengan jumlah santri 147), 5). PPHY (disebut Unit HY dengan jumlah santri 629), 6). PPDS (disebut Unit DS dengan jumlah santri 211), 7). PPMQ 281, 8). P3TQ 630, 9). PT3HMQ 289, 10). PPST al-Risa@lah 280, 11). PP Putra Putri al-Baqaroh 174. Selain itu, Pomdok Pesantren Lirboyo Kediri juga telah memiliki cabang dan semua santrinya tercatat sebagai santri Pondok Pesantren Lirboyo Kediri, yaitu; Cabang Pagu Kediri 212, Cabang Turen Malang 45, Cabang Bakung Blitar 130, santri duduk MHM 593, IAIT TRIBAKTI 1.141.Lihat Ketetapan Badan Pembina Pondok Psantren Lirboyo Periode 1434-1435 H (2013-2014 M)

${ }^{3}$ Badan ini memiliki otaritas tertinggi di lingkungan Pondok Pesantren Lirboyo. Semua kegiatan ataupun kebijakan di dalam pondok ataupun madrasah, hanya bisa direalisasikan ketika sudah mendapatkan restu dari BPKP2L. Apabila ada problematika yang belum bisa dipecahkan dalam sebuah rapat-rapat pengurus pesantren, baik induk maupun unit, hal itu kemudian diangkat dalam rapat BPK-P2L. (lihat; https://irboyo.net/pondok-unitlirboyo/)

${ }^{4}$ KH. Abdul Karim Lahir di desa Diyangan, Kawedanan, Mertoyudan, Magelang, Jawa Tengah pada tahun1856 M, dari pasangan Kiai Abdur Rahim Volume 29 Nomor 1 Januari-Juni 2018 
bernama Kyai Sholeh dan juga atas permintaan kepala desa Lirboyo kepada Kyai Sholeh agar berkenan menempatkan salah satu menantunya di desa Lirboyo yang terkenal wingit (angker). Setelah beberapa lama pondok pesantren Lirboyo berdiri dan telah memiliki banyak santri, KH.Abdul Karim memilih beberapa santrinya untuk menjadi menantunya, yaitu KH. Marzuki Dahlan dan KH. Mahrus Ali (nama kecilnya dipanggil Rusydi) yang kemudian kedua manantunya tersebut menjadi penerus kepemimpinan pesantren Lirboyo. Di tangang kedua menantunya ini, podok pesantren Lirboyo mengalami perkembangan yang sangat pesat dan berhail mendirikan perguruan tinggi yang bernama Universitas Islam Tribakti (sekarang Iinstitut Agama Islam tribakti Kediri).

Saat ini, kepemimpinan pesantren Lirboyo Kediri dipegang oleh generasi ketiga dan generasi keempat, yaitu cucu dan cicit dari KH. Abdul Karim. Sebagaimana teori Ashabiyah ${ }^{5}$ Ibnu Khaldun dalam bukunya "Muqadimah" menjelaskan bahwa generasi ketiga merupaka generasi yang rentan dengan konflik sehingga terjadinya konflik akan sangat rentan dengan perpecahan keruntuhan. Namun kenyataanya pesantren Lirboyo sampai saat ini masih tetap eksis dan justru mengalami perkembangan yang signifikan. Hal ini mengasumsikan bahwa kepemimpinan yang dijalankan oleh pesantren Lirboyo Kediri memiliki manajemen konflik yang baik.

Beberapa contoh konflik yang pernah terjadi dipesantren Lirboyo Kediri dan dapat dimanaj dengan baik adalah pertama, pendirian perguruan tinggi UIT (Universitas Islam Tribakti) yang diinisiasi oleh KH. Mahrus Aly. Banyak pihak yang tidak

dan Nyai Salamah. Beliau juga merupakan salah satu santri KH. Kholil Bangkalan Madura.

${ }^{5}$ Teori Ashabiyah/dinasti Ibnu Khaldun menyebutkan bahwa sebuah peradaban akan mengalami tiga tahapan, tahap pertama disebut 'perintis', tahap kedua disebut 'penikmat' dan tahap ketiga disebut 'penghancur'. 
menyetujui bahkan menentang gagasan tersebut dengan alasan menggagu proses pembelajaran di pesantren. Kedua, konflik tentang diperbolehkan atau tidaknya UIT menerima mahasiswa perempuan, ketiga, konflik tentang diterbitkannya kebijakan tentang tidak diperbolehkannya santri Lirboyo (Induk) untuk belajar di sekolah formal termasuk kuliah di UIT. Dan masih banyak lagi konflik yang pernah terjadi dan dapat dimanaj dengan baik melalui penerapan kepemimpinan kolektif.

Kepemimpinan kolektif di pesantren Lirboyo Kediri terdiri dari dewan masayikh (dewan kyai) yang berasal dari pengasuh masing-masing pesantren unit yang ada di Pesantren Lirboyo Kediri sebagaimana dijelaskan sebelumnya bahwa pesantren Lirboyo Kediri memiliki 11 unit. Dan masing-masing pengasuh dari pesantren unit tersebut tergabung kedalam organisasi BPK-P2L (Badan Pembina Kesejahteraan Pondok Pesantren Lirboyo) sebagai otoritas tertinggi atas kebijakan yang diputuskan oleh pesantren Lirboyo Kediri.

Berbicara mengenai kepemimpinan di pesantren, Hanun Asrohah dalam bukunya Pelembagaan Pesantren menyebutkan bahwa tradisi kepemimpinan pesantren merupakan tradisi yang diwariskan dari budaya dan tradisi Jawa pra-Islam, di mana buadaya dan tradisi jawa menganut sistem kasta yang mana kultur keturunan sangat kental. Dalam tradisi pra-Islam Lembaga pendidikan yang dipimpin oleh para Brahmana atau pendeta juga secara turun-temurun, penetapan sima swatanta atau perdikan juga secara turun-temurun. ${ }^{6}$ Tradisi inilah yang sampai saat ini dianut oleh banyak kalangan pesantren, di mana kepemimpinannya selalu jatuh pada keturunan kyai pesantren tersebut.

6 Hanun Asrohah, Pelembagaan Pesantren; Asal-usul dan Perkembangan Pesantren di Jawa (Jakarta: Depag RI, 2004). 
Kebanyakan pesantren di jawa didirikan atas inisiatif individu kyai, sehingga kepemilikan pesantren pun barada pada atas nama keluarga (dzuriyyah). Kepemilikan ini berimplikasi pada kepemimpinan pesantren. Kepemimpinan pesantren diteruskan secara turun-temurun. Kepemimpinan pesantren semacam ini menjadi tradisi pendidikan pesantren, ${ }^{7}$ demikian juga lembaga pendidikan modern yang secara historis didirikan atas inisiatif seorang kyai yang juga memimpin pesantren. Kepemimpinan lembaga pendidikan Islam modern akan selalu mengikuti pola kepeimpinan yang dilakukan oleh pesantren.

Abdurrahman Wahid yang akrab dengan panggilan Gus Dur dalam bukunya "Menggerakkan Tradisi" mengidentifikasi dan menyebut kepemimpinan tradisional pesantren sebagai kepemimpinan yang kharismatis. ${ }^{8}$ Biasanya lembaga pendidikan pesantren didirikan oleh seseorang yang bercita-cita tinggi dan mampu mewujudkan cita-citanya. Proses pendirian pesantren yang secara demikian menampilkan seorang pemimpin yang tertempa oleh pengalaman, memiliki keunggulan kepribadian yang dapat mengalahkan pribadi-pribadi lain disekitarnya. Kekuatan pribadi tersebut menciptakan corak kepemimpinan yang bersifat sangat pribadi, dan berlandaskan penerimaan masyarakat luar dan para santri secara mutlak. Sifat mutlak dan pribadi dari kepemipinan inilah yang disebut sebagai kharisma.

Hasil penelitian yang dilakukan oleh Sukamto yang berjudul 'Kepemimpinan Kyai dalam Pesantren' menyatakan bahwa kepemimpinan pesantren tergolong kedalam Gaya kepemimpinan otoriter/paternalistik di mana gaya kepemimpinan ini seringkali memberi lingkup yang sangat sempit terhadap

\footnotetext{
${ }^{7}$ Asrohah.

8 Abdurrahman Wahid, Menggerakkan Tradisi (Yogyakarta: L-Kis, 2001).
} 
kebebasan, kreatifitas dan inisiatif bawahan. ${ }^{9}$ Pihak bawahan selalu melakukan apa yang difatwakan oleh atasannya, pendapat dan inisiatif bawahan hampir tidak ada, kalaupun ada hanya merupakan usul yang menunggu kearifan Kyai. Dan sekiranya bawahan mempunyai inisiatif dan potensi tinggi ia hanya cukup untuk menjalankan fatwa Kyai. Dengan kata lain, apa yang dikatakan bawahan tidak akan pernah melampaui kewenangan Kyai.

Dari hasil penelitian yang dilakukan di berbagai pesantren, Mastuhu berkesimpulan bahwa gaya kepemimpinan pesantren terdiri dari beberapa corak, yaitu; kharismatik, otoriterpaternalistik, dan laissez-faire. ${ }^{10}$ Kepemimpinan kharismatik bersandar pada kepercayaan atau pandangan santri dan masyarakat umum bahwa kyai yang merupakan pemimpin pesantren mempunyai kekuasaan yang berasal dari Tuhan, berbeda dengan gaya kepemimpinan rasional yang bersandar pada kepercayaan atau pandangan santri dan masyarakat umum bahwa kyai mempunyai kekuasaan karena mempunyai ilmu pengetahuan yang dalam dan luas.

Berkenaan dengan perilaku kepemimpinan yang diterapkan oleh pesantren sebagaimana beberapa hasil penelitian diatas, dalam perkembangan selanjutnya menurut hemat penulis bahwa gaya kepemimpinan tersebut akan sangat rentan terjadinya konflik di internal pesantren. Konflik tersebut dapat bersumber pada kebijakan pemimpin peantren yang tidak mengakomodir seluruh kepentingan warga pesantren (khususnya para masyayikh dan pengurus). Konflik berarti persepsi mengenai perbedaan kepentingan (perceived divergence of interest) atau suatu

\footnotetext{
${ }^{9}$ Sukamto, Kepemimpinan Kyai dalam Pesantren (Jakarta: LP3ES, 1999).

10 Mastuhu, "Gaya dan Suksesi kepemimpinan Pesantren," Jurnal Ulumul Qur'an Vol. III (1994).

Volume 29 Nomor 1 Januari-Juni 2018 
kepercayaan bahwa aspirasi pihak-pihak yang berkonflik tidak dicapai secara simultan. ${ }^{11}$

\section{PEMBAHASAN}

\section{Kepemimpinan Konteks Pesantren}

Berbicara mengenai kepemimpinan di pondok pesantren, Hanun Asrohah dalam bukunya Pelembagaan Pesantren menyebutkan bahwa tradisi kepemimpinan pesantren merupakan tradisi yang diwariskan dari budaya dan tradisi Jawa pra-Islam, di mana buadaya dan tradisi jawa menganut sistem kasta yang mana kultur keturunan sangat kental. Dalam tradisi pra-Islam Lembaga pendidikan yang dipimpin oleh para Brahmana atau pendeta juga secara turun-temurun, penetapan sima swatanta atau perdikan juga secara turun-temurun. ${ }^{12}$ Tradisi inilah yang sampai saat ini dianut oleh banyak kalangan pesantren, di mana kepemimpinannya selalu jatuh pada keturunan kyai pesantren tersebut.

Kebanyakan pesantren di jawa didirikan atas inisiatif individu kyai, sehingga kepemilikan pesantren pun barada pada atas nama keluarga (zduriyyah). Kepemilikan ini berimplikasi pada kepemimpinan pesantren. Kepemimpinan pesantren diteruskan secara turun-temurun. Kepemimpinan pesantren semacam ini menjadi tradisi pendidikan pesantren, ${ }^{13}$ demikian juga lembaga pendidikan modern yang secara historis didirikan atas inisiatif seorang kyai yang juga memimpin pesantren. Kepemimpinan lembaga pendidikan Islam modern akan selalu mengikuti pola kepeimpinan yang dilakukan oleh pesantren.

11 Novri Susan, "Pengantar Sosiologi Konflik dan Isu-Isu Konflik Kontemporer. (Jakarta: Kencana. 2010)," t.t.

12 Asrohah, Pelembagaan Pesantren; Asal-usul dan Perkembangan Pesantren di Jawa.

13 Asrohah. 
Abdurrahman Wahid yang akrab dengan panggilan Gus Dur dalam bukunya "Menggerakkan Tradisi" mengidentifikasi dan menyebut kepemimpinan tradisional pesantren sebagai kepemimpinan yang kharismatis. ${ }^{14}$ Biasanya lembaga pendidikan pesantren didirikan oleh seseorang yang bercita-cita tinggi dan mampu mewujudkan cita-citanya. Proses pendirian pesantren yang secara demikian menampilkan seorang pemimpin yang tertempa oleh pengalaman, memiliki keunggulan kepribadian yang dapat mengalahkan pribadi-pribadi lain disekitarnya. Kekuatan pribadi tersebut menciptakan corak kepemimpinan yang bersifat sangat pribadi, dan berlandaskan penerimaan masyarakat luar dan para santri secara mutlak. Sifat mutlak dan pribadi dari kepemipinan inilah yang disebut sebagai kharisma.

Lebih lanjut Gus Dur menjelaskan bahwa watak kharismatik yang dimiliki oleh pemimpin pesantren dapat dilihat dari cara pengambilan keputusan yang semuanya bergantung pada pribadi sang pemimpin, sukarnya memperkirakan tentang tanggapan yang akan diberikan oleh sang pemimpin atas suatu usulan, pola pergantian pemimpin yang berlangsung secara tibatiba dan tidak direncanakan sehingga lebih banyak ditandai oleh sebab-sebab alami, ${ }^{15}$ seperti meninggalnya seorang pemimpin. Selain itu, penggati pemimpin yang baru dapat dipastikan mempunyai hubungan keluarga dengan pemimpin yang lama.

Sebagaimana yang dikatakan oleh Steenbrink bahwa :

Dalam mayarakat tradisional, seorang dapat menjadi kyai atau disebut kyai karena ia diterima masyarakat sebagai kyai, ...memang untuk menjadi kyai tidak ada kriteria formal seperti persyaratan studi, ijazah dan sebagainya. Akan tetapi ada beberapa syarat non

${ }^{14}$ Wahid, Menggerakkan Tradisi.

${ }^{15}$ Wahid.

Volume 29 Nomor 1 Januari-Juni 2018 
Manajemen Konflik ... Oleh: Zaenal Arifin

formal untuk menentukan seseorang untuk menjadi kyai besar atau kecil. ${ }^{16}$

\section{Tabel 1}

\section{Penelitian Terdahulu}

\begin{tabular}{|c|c|c|c|}
\hline $\begin{array}{l}\text { Tah- } \\
\text { un }\end{array}$ & Peneliti & $\begin{array}{l}\text { Tema/Judul } \\
\text { Penelitian }\end{array}$ & Hasil \\
\hline 1994 & Mastuhu & $\begin{array}{l}\text { Gaya dan Suksesi } \\
\text { Kepemimpinan } \\
\text { Pesantren }\end{array}$ & $\begin{array}{l}\text { Kharismatik, Otoriter- } \\
\text { patternalistik, laissez-faire }\end{array}$ \\
\hline 1999 & Sukamto & $\begin{array}{l}\text { Kepemimpinan } \\
\text { Kyai di } \\
\text { Pesantren }\end{array}$ & otoriter-paternalistik \\
\hline 2009 & Atiqullah & $\begin{array}{l}\text { Prilaku } \\
\text { Kepemimpinan } \\
\text { Kolektif di } \\
\text { Pesantren; }\end{array}$ & $\begin{array}{l}\text { perilaku kepemimpinan } \\
\text { kepemimpinan kolektif di pondok } \\
\text { pesantren terjadi dalam proses } \\
\text { pengambilan keputusan, } \\
\text { pengendalian konflik, dan } \\
\text { pembangunan tim }\end{array}$ \\
\hline 2010 & $\begin{array}{l}\text { Fathurrahman } \\
\text { Muhtar } \\
\text { (Disertasi) }\end{array}$ & $\begin{array}{l}\text { Konflik dalam } \\
\text { Pengelolaan } \\
\text { Lembaga } \\
\text { Pendidikan Islam } \\
\text { di Pondok } \\
\text { Pesantren }\end{array}$ & $\begin{array}{l}\text { Konflik memiliki fungsi sosial, } \\
\text { proses sosial, dan mendesak } \\
\text { adanya inovasi dan kreatifitas }\end{array}$ \\
\hline 2016 & Bashori & $\begin{array}{l}\text { Manajemen } \\
\text { Konflik di } \\
\text { Tengah } \\
\text { Dinamika } \\
\text { Pondok } \\
\text { Pesantren dan } \\
\text { Madrasah }\end{array}$ & $\begin{array}{l}\text { konflik yayasan dengan } \\
\text { masyarakat, yayasan dengan } \\
\text { pengasuh pondok pesantren, dan } \\
\text { konflik kyai dengan masyarakat. } \\
\text { resolusi konflik yang dilakukan } \\
\text { menggunakan model Obliging }\end{array}$ \\
\hline
\end{tabular}

${ }^{16}$ Karel A. Steenbrink, Beberapa Aspek tentang Islam di Indonesia Abad ke-19 (Jakarta: Bulan Bintang, 1984). 
Manajemen Konflik... Oleh: Zaenal Arifin

\begin{tabular}{|c|c|c|c|}
\hline 2016 & $\begin{array}{l}\text { Ali Muchsin } \\
\text { Disertasi }\end{array}$ & $\begin{array}{l}\text { Resolusi dan } \\
\text { Manajemen } \\
\text { Konflik } \quad \text { di } \\
\text { Institusi } \\
\text { Pendidikan } \\
\text { Islam }\end{array}$ & $\begin{array}{l}\text { Resolusi konflik dilakukan } \\
\text { hanya dipermukaan saja yaitu } \\
\text { dengan cara tabayyun dan } \\
\text { musyawarah serta menghadirkan } \\
\text { pihak ketiga yang dianggap } \\
\text { mempunyai kredibilitas. }\end{array}$ \\
\hline 2016 & Bashori & $\begin{array}{l}\text { Manajemen } \\
\text { Konflik di } \\
\text { Tengah } \\
\text { Dinamika } \\
\text { Pondok } \\
\text { Pesantren dan } \\
\text { Madrasah }\end{array}$ & $\begin{array}{l}\text { konflik yayasan dengan } \\
\text { masyarakat, yayasan dengan } \\
\text { pengasuh pondok pesantren, dan } \\
\text { konflik kyai dengan masyarakat. } \\
\text { resolusi konflik yang dilakukan } \\
\text { menggunakan model Obliging }\end{array}$ \\
\hline
\end{tabular}

Hasil penelitian yang dilakukan oleh Sukamto yang berjudul 'Kepemimpinan Kyai dalam Pesantren' menyatakan bahwa kepemimpinan pesantren tergolong kedalam Gaya kepemimpinan otoriter/paternalistik di mana gaya kepemimpinan ini seringkali memberi lingkup yang sangat sempit terhadap kebebasan, kreatifitas dan inisiatif bawahan. ${ }^{17}$ Pihak bawahan selalu melakukan apa yang difatwakan oleh atasannya, pendapat dan inisiatif bawahan hampir tidak ada, kalaupun ada hanya merupakan usul yang menunggu kearifan Kyai. Dan sekiranya bawahan mempunyai inisiatif dan potensi tinggi ia hanya cukup untuk menjalankan fatwa Kyai. Dengan kata lain, apa yang dikatakan bawahan tidak akan pernah melampaui kewenangan Kyai.

Berkenaan dengan gaya kepemimpinan otoriter/paternalitik, sistem organisasi yang dicantumkan dalam bentuk formal tidak seluruhnya berpengaruh terhadap mekanisme kerja sehari-hari. Pemetaan sistem administrasi didominasi oleh fatwa Kyai dan sangat jarang bersumber dari tugas dan fungsi

${ }^{17}$ Sukamto, Kepemimpinan Kyai dalam Pesantren.

Volume 29 Nomor 1 Januari-Juni 2018 
jabatan yang ditetapkan dalam organisasi. ${ }^{18}$ Sifat hubungan Kyai dan kariawan bawah dalam gaya kepemimpinan jenis ini menunjukkan tanda-tanda kekerabatan. Kyai dipandang sebagai kepala keluarga yang setiap saat mempunyai hak mutlak dalam menentukan gerak dan langkah organisasi.

Dari hasil penelitian yang dilakukan di berbagai pesantren, Mastuhu berkesimpulan bahwa gaya kepemimpinan pesantren terdiri dari beberapa corak, yaitu; kharismatik, otoriterpaternalistik, dan laissez-faire. ${ }^{19}$ Kepemimpinan kharismatik bersandar pada kepercayaan atau pandangan santri dan masyarakat umum bahwa kyai yang merupakan pemimpin pesantren mempunyai kekuasaan yang berasal dari Tuhan, berbeda dengan gaya kepemimpinan rasional yang bersandar pada kepercayaan atau pandangan santri dan masyarakat umum bahwa kyai mempunyai kekuasaan karena mempunyai ilmu pengetahuan yang dalam dan luas.

Gaya kepemimpinan otoriter adalah gaya kepemimpinan yang dilihat dari hubungan antara pimpinan dan bawahan yang sangat berbeda, bahwa pengaruh kyai sangat kuat dan partisipasi bawahannya hampir sama sekali tidak ada, dan kalaupun ada sangat kecil serta tidak berarti dibanding dengan pengaruh pimpinan (kyai). Sementara gaya kepemimpinan paternalistik hubungan antara pimpinan (kyai) dan bawahan bersifat kekeluargaan, kyai menganggap bahwa para santri adalah anakanaknya yang perlu diasuh sesuai dengan keinginan atau nilainilai yang dipercayai dan dianutnya, dan santri menganggap bahwa kyai adalah bapak yang harus dipatuhi. ${ }^{20}$

Terkait dengan gaya kepemimpinan yang bersentral pada otoritas kharismatik kyai dan hubungan yang bersifat otoriter-

\footnotetext{
${ }^{18}$ Sukamto.

${ }^{19}$ Mastuhu, "Gaya dan Suksesi kepemimpinan Pesantren."

${ }^{20}$ Mastuhu.
} 
paternalitik, gaya kepemimpinan laissez-faire berlandaskan pada pola dan hubungan kerja pesanren yang dilandaskan pada tiga kata kunci, yaitu, ikhlas, barakah, dan ibadah. Pesantren yang memiliki gaya kepemimpinan seperti ini memiliki tananan organisasi yang kurang jelas dan pembagian kerja antar unit pun tidak terpisahkan secara tajam, setiap pemimpn dalam satu unit bebas berinisiatif dan bekerja untuk kemajuan pesantren selama memperoleh restu dari kyai dan tidak bertentangan dengan aturan pesantren. $^{21}$

Selain menjelaskan tentang gaya kepemimpinan pesantren, Matsuhu juga menjelaskan pola pergantian kepemimpinan pesantren, di mana pola tersebut dimulai dari kakek (pendiri pertama pesantren), anak laki-laki, menantu, cucu, dan demikan seterusnya. Sehingga seorang anak laki-laki yang lebih senior dilihat dari kesalehannya atau kedalaman ilmu agamanya dan dianggap cocok menjadi kyai oleh masyarakat yang berhak menjadi ahli waris pertama. Dan jika anak laki-lakinya dianggap tidak cocok atau tidak mempunyai anak laki-laki maka ahli waris selanjutnya adalah menantu dan ahli waris ketiga adalah cucu. ${ }^{22}$

Atiqullah dalam penelitiannya yang berjudul "Varian Kepemimpinan Kolektif Pondok Pesantren di JawaTimur" menegaskan bahwa lahirnya kepemimpinan kolektif di pondok pesantren diasumsikan sebagai usaha bersama untuk mengisi jabatan baru sebagai tuntutan sosial masyarakat. ${ }^{23}$ Sementara penelitian mengenai konflik kepemimpinan pesantren, yaitu penelitian yang dilakukan oleh Fathurrahman Mukhtar dalam disertasinya yang berjudul "Konflik dalam Pengelolaan Lembaga Pendidikan Islam di Pondok Pesantren Nahdlatul Wathan

${ }^{21}$ Mastuhu.

22 Mastuhu.

23 Atiqullah, "Varian Kepemimpinan Kolektif Pondok Pesantren di Jawa Timur," Karsa, No. 1, Vol. 20 (2012).

Volume 29 Nomor 1 Januari-Juni 2018 
Lombok Timur Nusa Tenggara Barat". ${ }^{24}$ Pernelitian tersebut berfokus pada sumber konflik, peta konflik dan penyelesaian konflik yang terjadi di lembaga pendidikan Islam.

Sementara itu penelitian hasil penelitian Bashori mengenai manajemen konflik di pesantren yang berjudul "Manajemen Konflik di Tengah Dinamika Pesantren dan Madrasah" menemukan beberapa jenis konflik yang terjadi di pondok pesantren, diantaranya; konflik yayasan dengan masyarakat, yayasan dengan pengasuh pondok pesantren, dan konflik kyai dengan masyarakat. Dari model konflik yang terjadi tersebut, pendekatan resolusi konflik yang dilakukan utamanya menggunakan model Obliging (menetapkan nilai bahwa seseorang memiliki kemampuan lebih sehingga tidak merendahkannya). ${ }^{25}$ Lain halnya dengan hasil penelitian yang dilakukan oleh Ali Muchsin dalam disertasinya, yang berjudul "Resolusi dan Manajemen Konflik di Institusi Pendidikan Islam; Studi Kasus di Pondok Pesantren Al Ichsan Brangkal Sooko Mojokerto", berkesimpulan bahwa : 1) Konflik laten antar individu para elit berkembang menjadi konflik antar kelompok santri dan memanifestasi dalam bentuk perang urat syaraf. 2) Faktor penyebab konflik adalah dari faktor internal elit pesantren dan faktor eksternal yaitu; faktor ekonomi, perebutan kekuasaan, keluarga dan kewenangan politik, perbedaan pendidikan dan pandangan manajemen. 3) Konflik berimplikasi disfungsional terhadap pengelolaan pendidikan, yaitu dalam konteks struktur organisasi, konteks kepemimpinan, konteks fungsi-fungsi manajemen, konteks aspek manajemen. dan hilangnya kepercayaan masyarakat. 4) Resolusi konflik

24 Fathurrahman Mukhtar, "Konflik dalam Pengelolaan Lembaga Pendidikan Islam di Pondok Pesantren Nahdlatul Wathan Lombok Timur Nusa Tenggara Barat” (Disertasi, Doktoral, IAIN Sunan Ampel Surabaya, 2010).

25 Bashori, "Manajemen Konflik di Tengah Dinamika Pondok Pesantren dan Madrasah," Muslim Heritage, No. 2, Vol. I (November 2016). 190 Volume 29 Nomor 1 Januari-Juli 2018 
dilakukan hanya dipermukaan saja yaitu dengan cara tabayyun dan musyawarah serta menghadirkan pihak ketiga yang dianggap mempunyai kredibilitas. ${ }^{26}$

Selain itu, Muhammad Isnaini dalam tulisannya yang berjudul "Dinamika Kepemimpinan Kolektif Pesantren Sebagai Pusat Pendidikan Islam di Sumatera Selatan”, mengungkapkan bahwa sesungguhnya pesantren sangat membutuhkan lebih dari satu pemimpin. Hal ini dikarenakan unsur yang dapat dijadikan sebagai daya gerak kepemimpinan kolektif dalam pengelolaan sebuah pesantren di masa depan meliputi relasi sosial, sikap akomodatif, kepemimpinan spiritual kolektif, sense of belonging dan sense of responsibility, rasionalitas dan objektifitas. ${ }^{27}$

Dari penjelasan penelitian terdahulu diatas, posisi penelitian ini adalah memaknai tradisi manajemen konflik di Pondok Pesantren melalui penerapan kepemimpinan kolektif di Pesantren. Untuk lebih jelasnya dapat dilihat pada skema berikut ini :

26 Ali Muchsin, "Resolusi dan Manajemen Konflik di Institusi Pendidikan Islam, Studi Kasus di Pondok Pesantren Al Ichsan Brangkal Sooko Mojokerto" (Disertasi, Doktoral, IAIN Sunan Ampel Surabaya, 2016).

${ }^{27}$ Muhammad Isnaini, "Dinamika Kepemimpinan Kolektif Pesantren Sebagai Pusat Pendidikan Islam di Sumatera Selatan," Jurnal Pembangunan Manusia, 11, 4 (2010). 
Manajemen Konflik ... Oleh: Zaenal Arifin

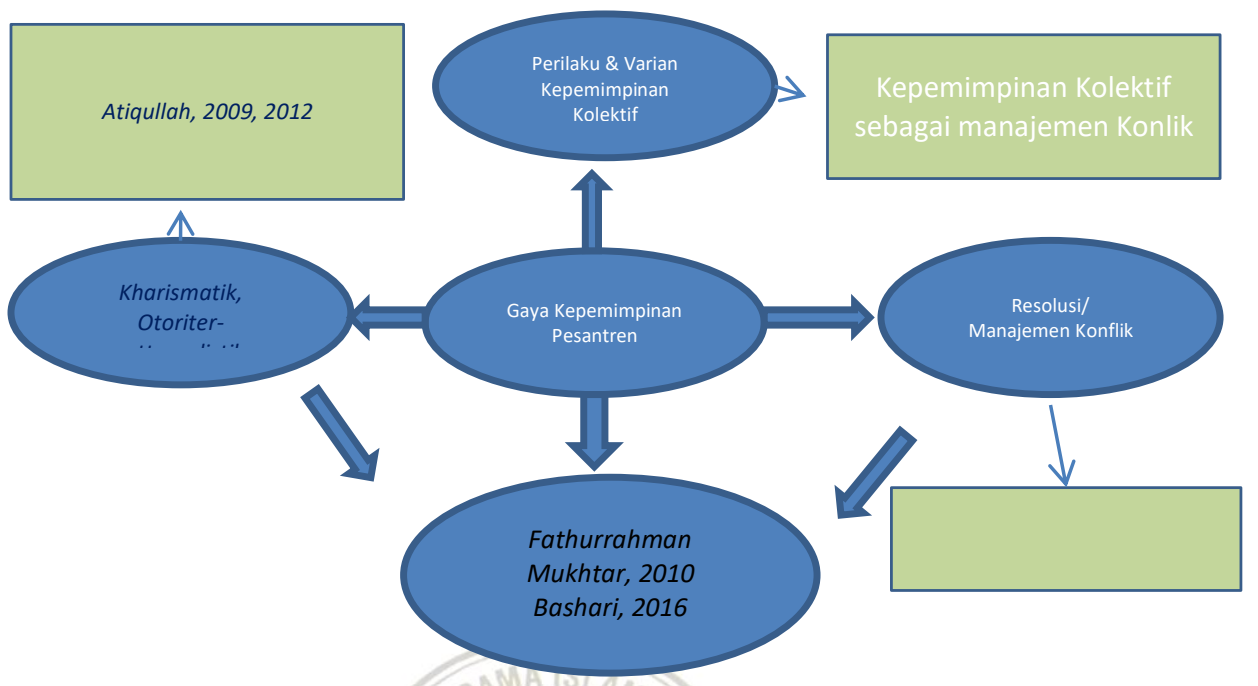

\section{Sejarah Kepemimpinan Pondok Pesantren Lirboyo Kediri}

Secara periodik, kepemimpinan pesantren Lirboyo Kediri terbagi kedalam empat periode yang terangkum kedalam tabal di bawah ini :

\begin{tabular}{|l|l|l|l|l|}
\hline No. & Periode & Pimpinan & $\begin{array}{l}\text { Masa } \\
\text { Kepemimpinan }\end{array}$ & $\begin{array}{l}\text { Gaya } \\
\text { Kepemimpinan }\end{array}$ \\
\hline 1 & $\begin{array}{l}\text { Periode } \\
\text { Pertama } \\
\text { (Perintisan) }\end{array}$ & $\begin{array}{l}\text { KH. Abdul } \\
\text { Karim }\end{array}$ & $1910-1954$ & $\begin{array}{l}\text { Kepemimpinan } \\
\text { Tunggal }\end{array}$ \\
\hline 2 & $\begin{array}{l}\text { Periode kedua } \\
\text { (Pengembang) }\end{array}$ & $\begin{array}{l}\text { KH. } \\
\text { Mazuki } \\
\text { Dahlan } \\
\text { KH. } \\
\text { Mahrus Aly }\end{array}$ & $1955-1985$ & $\begin{array}{l}\text { Kepemimpinan } \\
\text { Dwi Tunggal }\end{array}$ \\
\hline 3 & $\begin{array}{l}\text { Periode } \\
\text { keempat } \\
\text { (Generasi ke 3) }\end{array}$ & $\begin{array}{l}\text { Ketua : KH. } \\
\text { Idris } \\
\text { Marzuki } \\
\text { (Putra KH. } \\
\text { Marzuki } \\
\text { Dahlan) }\end{array}$ & $1985-2014$ & $\begin{array}{l}\text { Kepemimpinan } \\
\text { Kolektif }\end{array}$ \\
& & & \\
\hline
\end{tabular}


Manajemen Konflik... Oleh: Zaenal Arifin

\begin{tabular}{|l|l|l|l|l|}
\hline & BPK-P2L & 2014-Sekarang & Kepemimpinan \\
Ketua : KH. & & Kolektif \\
Anwar & & & \\
\hline
\end{tabular}

Pesantren Lirboyo secara usia telah mencapai satu abad lebih, berdirinya pondok pesantren ini pada 1910 oleh KH. Abdul Karim (mbah Manab, panggilan akrabnya). Pesantren ini memiliki unit-unit yang terhimpun dalam pondok ini, dan setiap pondok unit juga memiliki leader sendiri-sendiri namun masingmasing leader masih memiliki garis nasab (keturunan) dari muasisnya (pendiri). Pada masa awal berdirinya, pesantren Lirboyo Kediri hanya memiliki satu orang leader, yaitu $\mathrm{KH}$. Abdul Karim atau yang akrab dipanggil mbah Manab sebagai pendirinya. Kepemimpinan Muasis pondok pesantren Lirboyo berlangsung tahun 1910 hingga tahun 1954. Pada fase ini, segala urusan yang berkaitan dengan pondok berada di tangan sang pendiri.

Pada masa ini, waktu yang dimiliki oleh KH. Abdul karim lebih banyak digunakan untuk mentransferkan ilmunya pada santri, dan beliau merupakan pemegang otoritas tunggal pesantren. Pada tahun 1931 pesantren Lirboyo Kediri mendirikan madrasah diniyah atas inisiatif kiai Faqih (santri pindahan dari pesantren Tebu Ireng. Dengan berdirinya madrasah ini, KH. Abdul Karim merasakan banyak manfaat yang dimiliki, sehingga beliau mewajibkan semua santri yang bias membaca dan menulis untuk mengikuti madrasah diniyah yang menggunakan sistem klasikal.

Pada tahun 1936 dan 1938 KH. Abdul Karim mengambil menantu santri seniornya Mahrus Aly dan Marzuqi Dahlan, keduanya adalah santri senior yang menonjol kemampuanya. Kiai Marzuqi Dahlan merupakan cucu dari KH. Sholeh 
Banjarmelati, ${ }^{28}$ mulai usia remaja oleh kakeknya Gus Juki (panggilan kecil KH. Marzuki Dahlan) dipondokkan di Pesantren Lirboyo. Di pondok tersebut Gus Juki berguru kepada pamanya KH. Abdul Karim selama beberapa tahun, kemudian melanjutkan ke pesantren Tebuireng.

Sedangkan KH. Mahrus Aly putra dari KH Aly bin Abdul Aziz dari pesantren Kempek Ciwaringin Cirebon. Dengan dingkatnya kedua tokoh di atas yang juga santri senior sekaligus menantu KH. Abdul Karim sehingga memberi peluang untuk mengembangkan pesantren Lirboyo. Dari hubungan yang dekat ini terjadi proses transfer wewenang, kepemimpinan telah berlangsung pada petengahan periode ini dan puncaknya adalah perintah KH. Abdul Karim kepada Kiai Mahrus Aly yang menjadi cikal bakal pondok Unit HM dan Unit Al-Mahrusiyah. Kepemimpinan masa ini memiliki legitimasi yang sangat kuat pada periode awal berdirinya pesantren Lirboyo, dengan tidak melupakan kader dari penerus lainya.

Pasca meninggalnya muasis tahun 1954 pimpinan pesantren dilanjutkan dua menantu beliau Kiai Marzuqi Dahlan dan Kiai Mahrus Aly, dari kedua menantunya ini terjadi pembagian tugas antara keduanya, dalam beberapa urusan termasuk internal pesantren Kiai Mahrus tetap melakukan kordinasi dengan Kiai Marzuqi.

Kendati KH. Mahrus Aly memiliki hubungan luas di pesantren, namun beliau selalu berkordinasi meminta pertimbangan kepada KH. Marzuqi Dahlan dalam mengambil tindakan apapun. Antara Kiai Mahrus dan Kiai Marzuqi memiliki chimestri (harmonis) ikatan batin yang kuat. Hubungan yang kuat tersebut nampak dengan jelas ketika salah satu dari kedua tokoh

${ }^{28}$ Beliau merupakan mertua dari KH. Abdul Karim dan juga mertua dari KH. Dahlan Jampes, ayah dari KH. Ihsan Jampes (ulama yang mengarang banyak mengarang Kitab dan salah satunya adalah kitab dengan judul Sirajut Thalibin) 
tersebut sakit, maka sekali tempo mereka saling datang kerumah. Memang secara tertulis tidak ada pembagian tugas dalam kepemimpinan ke dua ini, namun terdapat pembagian peran namun tidak secara tertulis antara Kiai Mahrus Aly dan Kiai Marzuqi Dahlan. Kiai Mahrus Aly cenderung lebih banyak memegang peran urusan eksternal pesantren, karena ketokohan dan kepiawaian beliau dalam berorganisasi dikenal sebagai kiai yang disegani se-wilayah Kediri dan pada level Nasional. Tahun 1958 beliau menjadi Rois Syuriyah Pengurus Wilayah Nahdhatul Ulama Jawa Timur selama 27 tahun sampai wafat tahun 1985. Karena kesibukan aktifitas di luar Kiai Mahrus memiliki kedisiplinan dalam merencanakan dan menjadwal waktu kegiatan, di satu isi pesantren telah ada Kiai Marzuqi dan peranperan santri senoir yang lain yang berusaha menjalankan pendidikan yang ada di pondok pesantren.

Dalam hal tersebut pendelegasian wewenang merupakan fungsi dan bagian dari pelaksanaan manajemen yang ada dalam pesantren Lirboyo. Dalam kekosongan tugas mengajar Kiai Mahrus Aly menjadikan santri senoir menjadi berperan, nampak dalam pelaksanaan pengelolaan madrasah sehingga periode ini santri senior banyak berperan terhadap pengelolaan madrasah. Kepemimpian tahap ini mulai demokratis terlihat dari keterlibatan santri senior.

Ketika Kiai Mahrus Aly menjadi pimpinan beliau sering bergerak di luar dalam organisasi, karena keahlian dalam diplomasi dan retoriknya sehinggga dikagumi se-Kediri, sedangkan KH. Marzuki seorang alim sederhana termasuk seorang kiai yang bertasawuf yang lebih gayeng dengan rutinitas membaca dan mathala'ah kitab serta amalan dalail yang khatam 3 hari sekali. Kiai Marzuki lebih suka mengajar santri di pondok. Namun keduanya tetap saling menghormati dan kordinasi dalam perkembangan pondok. Termasuk dalam memegang sistem salaf di pesantren Lirboyo. 
Sifap kontrofersi antara kiai Marzuqi dan kiai Mahrus ini justru menjadikan pesantren Lirboyo menjadi menonjol dan tertata dengan baik, satu sisi kiai Mahrus dalam urusan eksternal di sisi yang lain Kiai Marzuqi. Dahlan urusan internal dengan ketasawufan ketegasan beliau. Karena pengaruh dari keluasan kiprah kiai Mahrus di luar dunia organisasi sehingga secara tidak langsung mempengaruhi gaya pemikiran dan gaya kepemimpinan beliau yang dulu otoriter menjadi demokratik, termasuk mendirikan Universitas Tribakti yang sekarang menjadi IAI Tribakti, dan membentuk badan pembina dengan istilah BPKP2L pada tahun 1966 menjadi nilai lebih bagi Lirboyo yang menaungi unit-unit di bawahnya.

Meskipun demikian berdirinya Universitas Tribakti kurang mendapat persetujuan dari kiai Marzuqi Dahlan. Dari generasi ke generasi ternyata pondok Induk Lirboyo membentuk BPK-P2L yang beranggotakan keterwakilan dari Dzuriyah Lirboyo yang didirikan oleh Kiai Mahrus sekaligus santri senior termasuk didalamnya, sebagai corong aspirasi bagi keluarga termasuk badan ini yang menentukan" Abang Ijone Pondok pesantren Lirboyo" mulai kapan tepatnya beliau lupa. Dalam badan ini sangat teratur terdapat moderator yang memimpin dalam musyawarah dan termasuk aturan-aturan musyawarah, mulai ada pendelegasian wewenang dan keikutsertaan santri senior yang menjadi pengurus.

\section{Kepemimpinan Kolektif Sebagai Pengendalian Konflik}

\section{Musyawarah}

Semangat kolektifitas yang dibangun oleh bani KH. Abdul Karim itulah yang menjiwai pesantren Lirboyo pada saat ini terus eksisis, pengaruh otoriter semkin menipis berubah menjadi kepemimpinan bersama yang demokratis dengan adanya BPKP2L karena dalam badan ini terdapat pendelegasian wewenang. Peran BPK P2L sebagai wadah dan media komunikasi para 
masyayikh pesantren Lirboyo dalam memecahkan problematika yang terjadi di unit-unit maupun di Induk, mulai persolan yang kecil hingga persolan yang besar.

Seorang pimpinan pesantren unit di Lirboyo tidak dapat memaksakan pendapatnya secara sepihak tetapi dalam beberapa hal pondok unit dapat mentukan kebijakan tetapi tetap dalam kordinasi dan musyawarah badan BPK-P2L. Perbedaan pendapat dalam sebuah pesantren sangat wajar dan sering terjadi permasalahan dan perbedaan pendapat drastisnya hingga terjadi perpecahan di dalamnya, seperti halnya badan BPK-P2L ini sebagai pemecah dan pemersatu mufatkat dalam pesantren Lirboyo ketika permasalahan tidak tuntas di tingkat himpunan pesantren (HP) akan dibawa dalam BPK-P2L.

Sebagaimana dituturkan oleh KH. Kafabihi Mahrus bahwa BPK-P2L didirikan oleh orang tua beliau dengan cara memanggil seluruh kerabat dan saudara untuk bermusyawarah membentuk BPK-P2L yang seluruh anggotanya terdiri merupakan Kyai dan Bani KH. Abdul Karim. Lanjut beliau KH. Abdulloh Kafabihi Mahrus bahwa badan ini berfungsi sebagai koordinasi dalam rangka memecahkan problematika dan kemajuan pesantren.

Kepemimpinan Kolektif di Pondok pesantren Lirboyo Kediri yang tercermin dalam organisasi yang dinamakan BPKP2L (Badan Pembina Kesejahteraan Pondok Pesantren Lirboyo Kediri) yang terbentuk pada tanggal 3 Sya'ban 1386/ 15 November 1966 atas inisiasi KH. Mahrus Aly dengan harapan agar seluruh keluarga besar pondok pesantren Lirboyo Kediri dapat terjaga keutuhannya dan dapat bekerja sama dengan baik. Badan ini merupakan pemegang otoritas tertinggi di lingkungan pondok pesantren Lirboyo Kediri dalam menentukan setiap kebijakan serta memiliki fungsi sebagai kontrol atas semua organisasi yang berada di bawah naungan pesantren Lirboyo Kediri. Setiap kebijakan yang akan direalisasikan baik oleh pengurus pondok maupun pengurus Madrasah Hidayatul Mubtadi'ien harus mendapatkan restu terlebih dahulu dari BPKP2L.

Struktur personalia BPK-P2L terbentuk sangat sederhana, yaitu hanya terdiri dari ketua, wakil ketua, sekretaris dan wakil sekretaris, dan anggota. 
Sementara jumlah total pengurus hanya terdiri dari 7-8 orang yang semuanya memiliki jalur nasab dengan pendiri pesantren Lirboyo Kediri yaitu KH. Abdul Karim. Sepeninggal KH. Idris Marzuki sebagai ini yang mejabat sebagai ketua BPK-P2L adalah KH. Anwar Mansur selaku pengasuh PP Lirboyo Unit Hidayatul Mubtadi'at. Terpilihnya KH. Anwar Mansur sebagai sebagai Ketua BPK-P2L terjadi beberapa bulan sepeninggal KH. Idris Marzuki yang terjadi dalam sebuah musyawarah pengurus BPK-P2L dimana dalam musyawarah tersebut tidak dihadiri oleh KH. Anwar Mansur. Gaya kepemimpinan pada periode ke tiga ketika setelah meninggalnya KH. Marzuqi Dahlan tahun 1975 dan wafatnya KH. Mahrus Aly pada tahun 1985 semakin meneguhkan fungsi kepemimpinan badan pembina (BPK-P2L). Walaupun badan ini didirikan sejak tahun 1966 mulai dirasakan keberadaannya periode ini. Wafatnya kiai Mahrus Aly menandai berakhirnya kepemimpinan generasi ke dua dari pesantren Lirboyo.

Adanya term pesantren kulon (barat) dan pesantren etan (timur) yang menjadi potensi adanya konflik dalam pengelolaan pesantren ini dapat terwadahi dalam BPK-P2L. Perebutan kepemimpinan dalam sebuah pondok pesantren sangat lazim apalagi sudah bergulir dari sang pendiri pesantren, karena kebijaksanaan kearifan masyayikh dalam menyikapi hal ini. Ketawadhu'an menjadi tolak ukur dalam pemilihan pimpinan sehinggga perpecahan tidak terjadi di Lirboyo.

\section{Pembagian Peran dan Wewenang}

Pembagian peran dan wewenang dalam kepemimpinan kolektif menjadi hal yang urgen untuk diaplikasikan, karena jika tidak, maka akan terjadi benturan antar masing-masing pemegang wewenang. Pembagian peran yang dilaksanakan BPK-P2L pesantren Lirboyo Kediri, terlihat bahkan sebelum dibentuknya badan tersebut, yaitu pada masa kepemimpinan KH. Marzuki Dahlan dan KH. Mahrus Ali. Sebagaimana dijelaskan pada paparan sebelumnya, bahwa KH. Marzuki Dahlan memiliki peran internal (persoalan proses pembelajaran di pesantren) dan $\mathrm{KH}$. 
Mahrus Ali berperan eksternal (urusan hubungan dengan dunia di luar pesantren).

Menurut KH. Abdulloh kafabihi Mahrus (Putra KH. Mahrus Ally), duet kepemimpinan antara KH. Marzuki Dahlan dan KH. Mahrus Ally merupakan duet kepemimpinan pesantren yang sangat ideal. Dimana KH. Marzuki Dahlan sebagai Kyai yang kental dengan karakter sufistik dan KH. Mahrus Ally yang memiliki hubungan yang luas dengan dunia di luar pesantren. Sehingga, dengan meninggalnya kedua tokoh ini membawa dampak yang sangat luar biasa terhadap keberlangsungan pesantren tersebut, terutama sosok pengganti dari duet kepemimpinan ideal tersebut.

Setelah BPK-P2L terbentuk, setiap anggota BPK-P2L memiliki peran dan fungsi sesuai dengan posisi yang didudukinya. Posisi ketua misalnya, memiliki peran sentral dalam roda keorganisasian, dan ketua BPK-P2L merupakan sosok yang sangat dihormati oleh anggota yang lainnya. Oleh karena itu, dalam penentuan siapa yang menjabat sebagai ketua, biasanya ditentukan oleh seberapa tua usia dan seberapa luas peran yang dilaksanakan selama ini. Sejalan dengan ini, menurut Syarqowi Dhofir, bahwa kekuasaan kyai tidak terletak pada satu figure saja, melainkan tercermin dalam kepemimpinan kolektif yang terwujud dalam dewan pimpinan. ${ }^{29}$

Selain itu, Pondok pesantren Lirboyo terdapat pengurus pesantren dan pengurus madrasah yang memiliki peran berbeda antara keduanya. Termasuk Organda, Organisasi Blok, Organisasi kamar semuanya sangat berperan dalam Lirboyo. Melihat paparan di atas kepemimpianan otoriter mulai berangsur berubah menjadi demokratis terbukti dengan keterlibatan santri senior dalam urusan pondok dan secara tugas dan wewenang mulai didelegasikan pada devisi-devisi.

29 Syarqowi Dhofir, Kekuasaan dan Otoritas Kyai dalam Pondok Pesantren (Surabaya: UNESA, 2014).

Volume 29 Nomor 1 Januari-Juni 2018 


\section{Tradisi Pernikahan antar Kerab}

Pernikahan merupakan salah satu anjuran dalam ajaran Islam sebagai media untuk menjaga keturunan dan menjalin persaudaraan. Secara sosilogis, ikatan pernikahan akan membentuk kehidupan sosial baru, yaitu relasi antara dua individu dan hubungan dua keluarga. Hubungan antar keluarga tersebut akan menghasilkan ikatan solidaritas yang kuat. Bahkan masyarakat jawa meyakini bahwa pernikahan bukan hanya mengikat dua individu antara laki-laki dan perempuan sebagai syarat untuk dihalalkannya hubungan biologis antara keduanya, namun sejatinya menyatukan dua keluarga antar pihak laki-laki dan perempuan. Sehingga terjalin hubungan dan timbulnya solidaritas yang kemudian disebut tali shilaturrahim atau relasi kekerabatan.

Sebagaimana hasil penelitian Zamakhsari Dhofir yang mengungkap bahwa jaringan kekerabatan antar ulama dan kiai NU di Jawa telah ada jauh sebelum NU lahir. Relasi kekerabatan, selain memiliki fungsi biologis, juga memiliki fungsi sosiologis. Menurut Moeflich Hasbullah jaringan kekerabatan antar ulama dan kiai di Jawa setidaknya memainkan empat peran dan fungsi sosial yang signifikan, yaitu, 1). Konsolidasi keberlangsungan hidup pesantren, 2). Perluasan keluarga dan dinasti kiai, 3). Pengembangan institusi pendidikan Islam, dan 4). Aktifitas Islam. ${ }^{30}$

Dari konteks tersebut, pesantren Lirboyo Kediri memiliki tradisi yang unik dalam melaksanakan tradisi kekerabatannya, yaitu dengan adanya tradisi pernikahan antar kerabat. Tradisi ini dimulai sejak tahun 1936, yaitu pada saat KH. Marzuki Dahlan diambil menantu oleh KH. Abdul Karim. Sebagaimana diketahui sebelumnya bahwa KH. Marzuki Dahlan merupakan cucu dari KH. Sholeh yang juga mertua KH. Abdul karim. Kemudian diikuti penikahan antara KH. M. Anwar Mashur ${ }^{31}$ dengan Umi

${ }^{30}$ Moeflich Hasbullah, Islam \& Transformasi Masyarakat Nusantara, 2 ed. (Depok: Kencana, 2017).

${ }^{31}$ Merupakan putra dari pasangan KH. Manshur dan Nyai Salamah, di mana Nyai Salamah merupakan putri ke-3 dari KH. Abdul Karim sang muasis pesantren Lirboyo Kediri 
Kulsum putri KH. Mahrus Alli. Dan terakhir pada tahun 2017, pernikahan sekerabat juga kembali dilaksanakan, yaitu antara $\mathrm{H}$. Ahmad Kafa putra dari KH. Abdulloh Kafabihi Mahrus dengan Sheilla Hasinah Zamzami putri dari KH. Hasan Zamzami Mahrus, dimana KH. Hasan Zamzami Mahrus merupakan adik kandung dari KH. Abdulloh Kafabihi Mahrus.

Sebenarnya masih banyak pernikahan antar kerabat yang dilaksanakan oleh dzuriyah pesantren Lirboyo Kediri, dan penulis meringkasnya dalam bagan di bawah ini:

\begin{tabular}{|c|c|c|}
\hline $\begin{array}{ll}\text { KH. Marzuki Dahlan } & \\
\text { (Cucu } & \text { KH. } \\
\text { Sholeh/Keponakan } & \text { KH. } \\
\text { Abdul Karim) } & \end{array}$ & $\begin{array}{l}\text { Menikah } \\
\text { dengan }\end{array}$ & $\begin{array}{l}l \\
\text { Nyai Maryam } \\
\text { (Putri KH. KH. Abdul } \\
\text { Karim/Cucu KH. Sholeh) }\end{array}$ \\
\hline $\begin{array}{l}\text { KH. M. Anwar Manshur } \\
\text { (Putra KH. Mansur/Cucu } \\
\text { KH. Abdul Karim) }\end{array}$ & $\begin{array}{l}\text { Menikah } \\
\text { dengan }\end{array}$ & $\begin{array}{l}\text { Nyai Umi Kulsum } \\
\text { (Putri KH. Mahrus Ali /Cucu } \\
\text { KH. Abdul Karim) } \\
\end{array}$ \\
\hline $\begin{array}{l}\text { KH. Abdul Aziz Mansur } \\
\text { (Putra KH. Mansur/Cucu } \\
\text { KH. Abdul Karim) }\end{array}$ & $\begin{array}{l}\text { Menikah } \\
\text { dengan }\end{array}$ & $\begin{array}{l}\text { Nyai Muslihah } \\
\text { (Putri KH. Marzuki Dahlan } \\
\text { /Cucu KH. Abdul Karim) }\end{array}$ \\
\hline $\begin{array}{l}\text { Muhammad Kafa } \\
\text { (Putra KH. Abdulloh } \\
\text { Kafabihi Mahrus/Cucu KH. } \\
\text { Mahrus Ali) }\end{array}$ & $\begin{array}{l}\text { Menikah } \\
\text { dengan }\end{array}$ & $\begin{array}{l}\text { Ny. Thu'thi Amanah Nafisah } \\
\text { (Putri KH. Idris } \\
\text { Marzuki/Cucu KH. Marzuki } \\
\text { Dahlan) }\end{array}$ \\
\hline 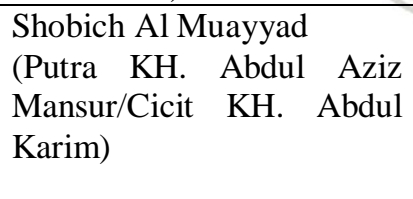 & $\begin{array}{l}\text { Menikah } \\
\text { dengan }\end{array}$ & $\begin{array}{l}\text { Arwa Fathimatuz Zahro' } \\
\text { (Putra KH. Abdulloh } \\
\text { Kafabihi Mahrus/Cucu KH. } \\
\text { Mahrus Ali/Cicit KH. Abdul } \\
\text { Karim) }\end{array}$ \\
\hline 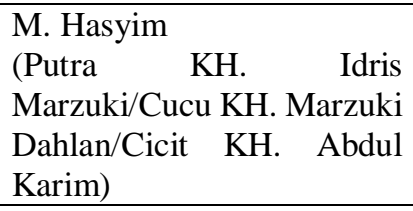 & $\begin{array}{l}\text { Menikah } \\
\text { dengan }\end{array}$ & $\begin{array}{l}\text { Jihan Zainab Zamzami } \\
\text { (Putri KH. Hasan Zamzami } \\
\text { Mahrus/Cucu KH. Mahrus } \\
\text { Ali/ Cicit KH. Abdul Karim) }\end{array}$ \\
\hline $\begin{array}{l}\text { Ahmad Kafa } \\
\text { (Putra KH. Abdulloh } \\
\text { Kafabihi Mahrus/Cucu KH. } \\
\text { Mahrus Ali/Cicit KH. } \\
\text { Abdul Karim) }\end{array}$ & $\begin{array}{l}\text { Menikah } \\
\text { dengan }\end{array}$ & $\begin{array}{l}\text { Nur Sheila Hasina } \\
\text { (Putri KH. Hasan Zamzami } \\
\text { Mahrus/Cucu KH. Mahrus } \\
\text { Ali/ Cicit KH. Abdul Karim) }\end{array}$ \\
\hline
\end{tabular}

Persoalan mengenai siapa saja yang dapat dinikahi oleh seorang individu dalam Islam telah diatur dengan jelas dalam Al Quran surah An Nisaa ayat 23. Dalam ayat tersebut hanya menyebutkan siapa saja perempuan yang haram untuk dinikahi, 
dan selainnya diperbolehkan. Sehingga pada konteks ini. Berdasarkan pernyataan KH. M. Anwar Manshur selaku ketua BPK-P2L dalam sambutannya dalam acara akad nikah antara Muhammad Kafa dengan bahwa salah satu alasan mengapa keluarga Pesantren Lirboyo Kediri menikah dengan kerabat ialah bahwa Islam mengajarkan untuk menikahi orang yang memiliki bobot, bibit, dan bebet yang jelas dan baik, sehingga keturunan yang dihasilkan juga akan baik. Hal ini menegaskan penelitian yang dilakukan oleh Siti Zya Ama yang berjudul "Pernikahan Kekerabatn Bani Kamsidin, Studi Kasus Pernikahan Endogami di Jawa Timur Tahun 1974-2015 M" yang menyatakan bahwa pernikahan endogami didasari atas keyakinan agama, menjaga keturunan, dan menjaga keutuhan keluarga. ${ }^{32}$

Secara sosiologis, pernikahan dengan kerabat dekat selain memiliki fungsi mempererat hubungan kerabat juga memiliki fungsi yang sama dengan fungsi pernikahan endogami, yaitu menjaga kelestarian keluarga dan keturunan/nasab, memperkuat hubungan kekerabatan. Hubungan kekerabatan yang kuat akan memunculkan rasa solidaritas yang tinggi, sehingga diharapkan dengan adanya rasa solidaritas yang tinggi antar kerabat dapat meminimalisir konflik yang muncul. Seandainya pun ada konflik yang muncul, maka penyelesaiannya cukup menggunakan pendekatan kekerabatan.

\section{KESIMPULAN}

Berdasarkan pada pembahasan di atas, dapat penulis tarik beberapa kesimpulan sebagai berikut:

Pertama, bahwa pembentukan BPK-P2L pesantren Lirboyo Kediri dadasari atas motif untuk menjaga keutuhan ikatan kekerabatan dzuriah pesantren Lirboyo dan juga sebagai wadah otoritas tertinggi dalam menyelesaikan persoalanpersoalan yang timbul karena perbedaan dan konflik.

Kedua, potensi konflik yang ada di pesantren Lirboyo

${ }^{32}$ Siti Zya Ama, "Pernikahan Kekerabatan bani Kamsidin; Studi Kasus Pernikahan Endogami di Jawa Timur Tahun 1974-2015 M," Jurnal Sejarah Peradaban Islam, No. 2, Vol. 1 (2017). 
Kediri dapat dipetakan menjadi 3 (tiga) macam, yaitu; 1). BPKP2L Pesantren Lirboyo Kediri merupakan otoritas tertinggi, sementara Pesantren Lirboyo Kediri memiliki unit-unit pesantren yang berdiri sendiri dan memiliki pengasuh serta organisasi tersendiri, 2). Term pondok kulon dan pondok wetan, 3). Pembagian peran, jika dalam pembagian peran tidak bias mengakomodir seluruh pihak yang berkepentingan, maka hal ini akan menjadi potensi konflik tersendiri.

Ketiga, bahwa kepemimpinan kolektif yang diimplementasikan oleh BPK-P2L pesantren Lirboyo Kediri dalam rangka pengendalian konflik yang muncul adalah dengan pendekatan musayawarah, pembagian peran dan wewenang, serta menerapkan tradisi pernikahan antar kerabat. Pernikahan antar kerabat yang diterapkan oleh pesantren Lirboyo Kediri meskipun secara implisit tersurat di dalam sistem kepemimpinan kolektif BPK-P2L, namun tradisi ini menjadi alat yang sangat efektif untuk menjaga keutuhan keluarga dalam rangka mengendalikan konflik yang muncul karena adanya pihak luar yang masuk menjadi bagian dari keluarga. 
Ama, Siti Zya. "Pernikahan Kekerabatan bani Kamsidin; Studi Kasus Pernikahan Endogami di Jawa Timur Tahun 19742015 M." Jurnal Sejarah Peradaban Islam, No. 2, Vol. 1 (2017).

Asrohah, Hanun. Pelembagaan Pesantren; Asal-usul dan Perkembangan Pesantren di Jawa. Jakarta: Depag RI, 2004.

Atiqullah. "Varian Kepemimpinan Kolektif Pondok Pesantren di Jawa Timur." Karsa, No. 1, Vol. 20 (2012).

Bashori. "Manajemen Konflik di Tengah Dinamika Pondok Pesantren dan Madrasah." Muslim Heritage, No. 2, Vol. I (November 2016).

Dhofir, Syarqowi. Kekuasaan dan Otoritas Kyai dalam Pondok Pesantren. Surabaya: UNESA, 2014.

Hasbullah, Moeflich. Islam \& Transformasi Masyarakat Nusantara. 2 ed. Depok: Kencana, 2017.

Isnaini, Muhammad. "Dinamika Kepemimpinan Kolektif Pesantren Sebagai Pusat Pendidikan Islam di Sumatera Selatan.” Jurnal Pembangunan Manusia, 11, 4 (2010).

Mastuhu. "Gaya dan Suksesi kepemimpinan Pesantren.” Jurnal Ulumul Qur'an Vol. III (1994).

Muchsin, Ali. "Resolusi dan Manajemen Konflik di Institusi Pendidikan Islam, Studi Kasus di Pondok Pesantren Al Ichsan Brangkal Sooko Mojokerto.” Disertasi, Doktoral, IAIN Sunan Ampel Surabaya, 2016.

Mukhtar, Fathurrahman. "Konflik dalam Pengelolaan Lembaga Pendidikan Islam di Pondok Pesantren Nahdlatul Wathan 
Lombok Timur Nusa Tenggara Barat.” Disertasi, Doktoral, IAIN Sunan Ampel Surabaya, 2010.

Steenbrink, Karel A. Beberapa Aspek tentang Islam di Indonesia Abad ke-19. Jakarta: Bulan Bintang, 1984.

Sukamto. Kepemimpinan Kyai dalam Pesantren. Jakarta: LP3ES, 1999.

Susan, Novri. "Pengantar Sosiologi Konflik dan Isu-Isu Konflik Kontemporer. (Jakarta: Kencana. 2010),” t.t.

Wahid, Abdurrahman. Menggerakkan Tradisi. Yogyakarta: LKis, 2001. 